\title{
DISTRIBUSI VERTIKAL KARANG BATU (SCLERACTINIA) DI PERAIRAN DESA KALASEY, KABUPATEN MINAHASA
}

\author{
(Vertical Distribution of Stony Coral at Kalasey Waters, \\ Regency of Minahasa)
}

\section{Willy Fredy Lasano ${ }^{1 *}$, Fontje Goeris Kaligis ${ }^{1}$, Janny Dirk Kusen ${ }^{1}$}

\author{
1. Program Studi IImu Kelautan, Fakultas Perikanan dan IImu Kelautan, Universitas Sam \\ Ratulangi, Manado \\ `e-mail :willylasano@yahoo.com
}

The aims of this research were to know community structure and vertical distribution of Scleractinia coral at Kalasey waters. 48 species were found at reef slope and 38 species were found at reef flat. The number of colony at reef slope were 190 and 133 at the reef flat. Species Porites lobata have highest relative density at reef slope and species Favites halicora at the reef flat with $20 \%$. The diversity indeks shown the high diversity at reef slope (3.12) and medium diversity at flat reef (2.95). As generaly, reef slope and reef flat have one kind of distribution. Indeks average at reef slope is 0.80 and 0.81 at the reef flat. Both value at reef slope and reef flat are known as stabil community .

Keywords: Scleractinia, vertical distribution, community structure

Penelitian ini dilaksanakan dengan tujuan untuk mengetahui struktur komunitas dan distribusi vertikal karang scleractinia di perairan Desa Kalasey. Jumlah spesies yang ditemukan pada lereng terumbu berjumlah 48 dan pada rataan terumbu 38. Jumlah koloni pada lereng terumbu berjumlah 190 dan pada rataan terumbu 133. Spesies Porites lobata memiliki kepadatan relatif tertinggi pada lereng terumbu dan Favites halicora pada rataan terumbu, masing-masing dengan nilai $20 \%$. Nilai indeks keanekaragaman menunjukkan keanekaragaman tinggi pada lereng terumbu $(3,12)$ dan keanekaragaman sedang pada rataan terumbu $(2,95)$. Secara umum, kedua loaksi tersebut memiliki pola penyebaran seragam. Hasil indeks kemerataan pada lereng terumbu 0,80 dan rataan terumbu 0,81 . Kedua nilai tersebut digolongkan pada komunitas yang stabil.

Kata kunci: Scleractinia, distribusi vertikal, struktur komunitas

\section{PENDAHULUAN}

Terumbu karang adalah struktur di dasar laut berupa deposit kalsium karbonat yang dihasilkan terutama oleh hewan karang. Dikatakan Brown at all. (2004) bahwa sebagian besar terumbu karang dapat ditemukan pada $20^{\circ}$ Lintang Utara sampai $20^{\circ}$ Lintang Selatan. Gosliner dkk (1996) bahwa faktor yang paling menentukan sebaran terumbu karang yaitu temperatur, kedalaman serta intensitas cahaya, salinitas, pergerakan air dan sedimentasi.

Karang Scleractinia sendiri sering mendapat tekanan dari lingkungan sekitar, baik dari aktifitas manusia ataupun dari aktifitas alam.

Menurut Burke \& Spalding (2002) ancaman utama terumbu karang ialah penangkapan ikan berlebihan, praktek penangkapan ikan yang merusak, sedimentasi serta pencemaran yang berasal dari daratan. Dahuri (2003) berpendapat menyatakan bahwa terumbu karang merupakan suatu ekosistem yang sangat rentan terhadap ganguan akibat kegiatan manusia dan pemulihannya memerlukan waktu yang lama. 


\section{METODE PENELITIAN}

Penelitian ini dilaksanakan di perairan Desa Kalasey, Kabupaten Minahasa Pengambilan data di lapangan menggunakan metode belt transek kuadran. Penelitian ini berlangsung selama bulan Maret, April dan Mei 2013.

Belt transek kuadran digunakan untuk mengambarkan kondisi populasi suatu jenis karang yang mempunyai ukuran relatif beragam atau mempunyai ukuran maksimum tertentu (Johan, 2003). Transek diletakkan pada masingmasing titik yang telah ditentukan dan ditarik dari arah laut ke darat atau tegak lurus terhadap garis pantai. Kuadran kemudian diletakkan di atas transek yang ada.

Selanjutnya adalah kegiatan pemotretan terhadap organisme karang Scleractinia yang terdapat di dalam masing-masing kuadran. Hasil gambar tersebut kemudian diidentifikasai menggunakan buku-buku panduan identifikasi.

Kegiatan berikutnya adalah untuk mengidentifikasi spesies karang Scleractinia yang telah difoto. Proses identifikasi dilakukan secara bertahap, yaitu pengelompokan dimulai dari tingkat genus berdasarkan ciri-ciri yang ditampilkan sebelum memasuki tahap identifikasi spesies.



Gambar 1. Lokasi penelitian

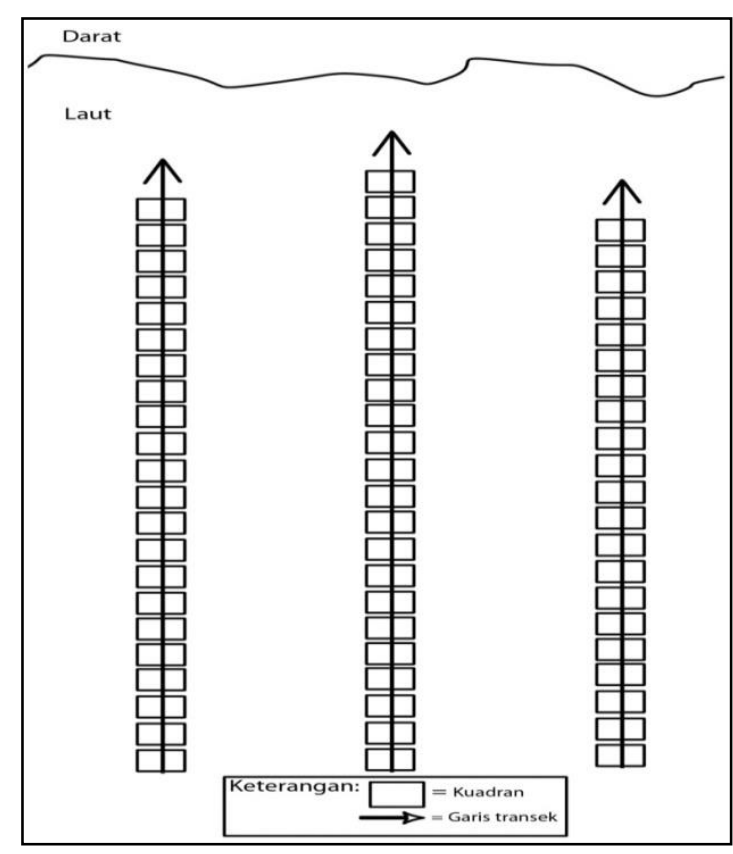

Gambar 2. Pola pemasangan belt transek kuadran.

Pengelompokkan dalam tingkatan genus dilakukan dengan melihat bentuk pertumbuhan yang ada pada gambar, kemudian di cocokkan dengan panduan identifikasi yang ada. Setelah genus ditentukan, langkah selanjutnya adalah menentukan spesies dengan melihat karakter yang sama antara foto sampel dengan panduan identifikasi, seperti warna dan bentuk koralit.

\section{HASIL DAN PEMBAHASAN}

Struktur terumbu pada lokasi penelitian terdiri dari lereng dan rataan. Dimana kuadran 1 sampai 10 berada di lereng terumbu dengan jumlah 37 kuadran dan kuadran 11 sampai 24 berada pada rataan terumbu dengan jumlah 30 kuadran.

Dari hasil penelitian diperoleh 63 spesies karang Scleractinia dari 24 genera yang masuk dalam 12 famili dengan jumlah koloni 323. Substrat pada lokasi penelitian berupa pasir dengan campuran patahan karang mati. Sedangkan pada substrat yang keras banyak dihuni oleh biota-biota selain karang Scleractinia, seperti sponge, alga, karang lunak dan moluska. Menurut 
Romimohtarto (2009) bahwa terumbu karang merupakan ekosistem yang subur dan kaya akan makanan. Oleh sebab itu penghuni terumbu karang sangat beranekaragam, baik yang berupa tumbuh-tumbuhan maupun hewan.

\section{Kepadatan Relatif}

Kepadatan relatif pada lereng terumbu ditemukan pada spesies Porites lobata dan pada rataan terumbu ditemukan pada spesies Favites halicora masing-masing dengan nilai $20 \%$. Menurut Pitasari dan Aunurohim (2011) Porites adalah salah satu karang yang bereproduksi dengan cara brooding, dimana larva yang dihasilkan sudah memiliki septa dan alga zooxanthellae yang berkontribusi sebagai penghasil energi bagi larva selama proses penempelan. Selain itu, larva dari mekanisme brooding ini mampu langsung menempel pada substrat, sehingga tingkat rekrutmennya tinggi.

Selain Porites, karang dengan bentuk pertumbuhan massive seperti Favites juga banyak dijumpai. Menurut Siringoringo (2012) karang yang berada pada kedalaman 1- $3 \mathrm{~m}$ didominasi oleh jenis massive yang tahan terhadap kondisi lingkungan yang ekstrim.

\section{Indeks Keanekaragaman}

Keanekaragaman tertinggi ditemukan pada lereng terumbu dengan nilai 3,12 dan keanekaragaman sedang ditemukan pada rataan terumbu dengan nilai 2,95. Di lereng terumbu ditemukan 48 spesies dari 23 genera dan di rataan ditemukan 38 spesies dari 18 genera. Sedangkan jumlah koloni pada lereng terumbu berjumlah 190 koloni dan pada rataan berjumlah 133 koloni.

Pada daerah lereng terumbu jumlah spesiesnya lebih banyak jika dibandingkan dengan daerah yang lebih dangkal. Hal ini mungkin saja terjadi karena diduga daerah dangkal adalah dearah yang paling mudah terkena dampak sedimentasi. Mengingat lokasi penelitian berdekatan dengan daerah penimbunan, sehingga sedimen dari daerah penimbunan dapat terbawa masuk ke perairan.

\section{Indeks Penyebaran Morishita}

Pola sebaran pada lereng terumbu yaitu 32 spesies memiliki pola penyebaran seragam dan 16 spesies memilik pola penyebaran mengelompok. Dan pada rataan terumbu ditemukan 27 spesies memiliki pola penyebaran seragam dan 11 spesies memiliki pola penyebaran mengelompok.

Pola penyebaran seragam diduga karena ketersediaan makanan yang kurang dan juga banyak terdapat organisme lain yang bersaing dengan karang Scleractinia seperti persaingan dalam mendapatkan ruang sehingga karang Scleractinia di lokasi penelitian menunjukkan pola penyebaran seragam.

\section{Indeks Kemerataan}

Nilai indeks kemerataan pada lereng terumbu sebesar 0,80 dan pada rataan terumbu memiliki nilai sebesar 0,81 . Kedua nilai tersebut masih digolongkan pada komunitas stabil. Kedua nilai tersebut masih digolongkan pada komunitas yang stabil.

Nilai indeks kemerataan pada lereng terumbu lebih rendah jika dibandingkan dengan rataan terumbu. Nilai ini berbanding terbalik dengan nilai indeks keanekaragaman. Dimana hasil indeks keanekaragaman menunjukkan keanekaragaman tinggi pada lereng terumbu dan keanekaragaman sedang pada rataan terumbu. Seharusnya semakin beragam suatu komunitas maka semakin merata pula distribusi spesies pada komunitas tersebut. Namun hal ini dapat terjadi karena jumlah kuadran pada kedua lokasi tersebut berbeda jumlahnya. Jumlah kuadran pada rataan terumbu yaitu 37 kuadran dan pada lereng terumbu berjumlah 30 kuadran. Dengan demikian area distribusi karang pada rataan terumbu lebih luas dibandingkan dengan lereng terumbu. Sehingga memungkinkan untuk nilai indeks kemerataan lebih tinggi pada rataan terumbu dan lebih rendah pada lereng terumbu. 


\section{Distribusi Vertikal}

Untuk melihat distribusi maka hasil ditampilkan secara vertial. Tabel 1 menampilkan hasil dari komponenkomponen yang dihitung. Komponenkomponen yang dihitung dikelompokkan menjadi dua, yaitu rataan terumbu dan lereng terumbu. Jumlah spesies dan jumlah koloni lebih tinggi pada lereng terumbu dibandingkan dengan rataan terumbu. Arus dan sirkulasi air juga berperan dalam proses sedimentasi.

Sedimentasi dari partikel lumpur padat yang dibawa oleh aliran permukaan (surface run off) akibat erosi dapat menutupi permukaan terumbu karang sehingga tidak hanya berdampak negatif terhadap hewan karang tetapi juga terhadap biota hidup yang berasosiasi dengan habitat tersebut (Dahuri, 2003). Menurut Nababan (2009) kebanyakan hewan karang tidak dapat bertahan karena adanya endapan yang menutupinya sehingga menyumbat struktur pemberian makanannya.

Tabel 1. Komponen komunitas pada lereng terumbu dan rataan terumbu

\begin{tabular}{|l|c|c|}
\hline \multirow{2}{*}{$\begin{array}{c}\text { Komponen } \\
\text { Komunitas }\end{array}$} & \multicolumn{2}{c|}{ LOKASI } \\
\cline { 2 - 3 } & $\begin{array}{c}\text { Rataan } \\
\text { terumbu }\end{array}$ & $\begin{array}{c}\text { Lereng } \\
\text { terumbu }\end{array}$ \\
\hline $\begin{array}{l}\text { Jumlah kuadran } \\
\text { (n) }\end{array}$ & 37 & 30 \\
\hline Jumlah spesies & 38 & 48 \\
\hline Jumlah koloni & 133 & 190 \\
\hline $\begin{array}{l}\text { Indeks } \\
\text { keanekaragaman } \\
\text { (H') }\end{array}$ & 2,95 & 3,12 \\
\hline H maksimum & 3,63 & 3,87 \\
\hline $\begin{array}{l}\text { Indeks } \\
\text { kemerataan }\end{array}$ & 0,81 & 0,80 \\
\hline
\end{tabular}

\section{KESIMPULAN}

Berdasarkan hasil penelitian ditemukan 63 spesies karang Scleractinia dari 24 genus dan 12 famili dengan jumlah koloni 323 , dengan kepadatan relatif tertinggi pada spesies $P$. lobata (lereng terumbu) dan $F$. halicora (rataan terumbu). Lereng terumbu memiliki keanekaragaman tinggi dengan nilai 3,12 dan pada rataan terumbu memiliki keanekaragaman sedang dengan nilai 2,95.

Pada lereng terumbu ditemukan 32 spesies memiliki pola penyebaran seragam dan 16 spesies mengelompok. Pada rataan terumbu ditemukan 27 spesies memiliki pola penyebaran seragam dan 11 spesies mengelompok. Nilai indeks kemerataan pada lereng terumbu sebesar 0,80 dan rataan terumbu sebesar 0,81. Kedua nilai tersebut masih digolongkan pada komunitas yang stabil.

\section{DAFTAR PUSTAKA}

Burke L., Selig E. \& Spalding M. 2002. Terumbu Karang yang Terancam di Asia Tenggara. World Resourches Institute. Amerika Serikat. 44 halaman

Brown R., Gruber. J.G., Hardesty J., Meyer M., Roth M., Thompson J. \& Weir W. 2004. Reef Relief the Coral Reef Theacher Guide.Captain Roland Roberts House Environmental Center. AbacosBahamas. 175 hal.

Dahuri R. 2003. Keanekaragaman Hayati Laut-Aset Pembangunan Berkelanjutan Indonesia. Gramedia Pustaka Utama. Jakarta. 412 halaman

Gosliner T. M., Behrens D. W., Williams G. C. 1996. Coral Reef Animal of the Indo-Pacific. Colographics, Monterey. California. 314 hal.

Johan O. 2003. Metode Survey Terumbu Karang Indonesia. Disampaikan pada acara Training Course: Karakteristik Biologi Karang. PSKUI dan Yayasan TERANGI. Diunggah 25 Oktober 2013, dari www.terangi.or.id. 
Nababan T. M. 2009. Persen Tutupan (Percent Cover) Terumbu Karang Hidup di Bagian Timur Perairan Pulau Rubiah Nanggroe Aceh Darussalam. Skripsi - Universitas Sumatera Utara. 69 halaman

Pitasari A., Saptarini D. \& Aunurohim. 2011. Tingkat Rekrutmen Karang pada Tiga Tipe Substrat di Pantai Pasir Putih Situbondo. Institute Teknologi Sepuluh Nopember Surabaya.

Rogers C. S. 1990. Responses of Coral Reefs and Reef Organism to Sedimantation. Marine Ecology Progress Series. Virginia Islands. 10 halaman

Romimohtarto K., Juwana S. 2009. Biologi Laut-IImu Pengetahuan Tentang Biota Laut. Djambatan. Jakarta. 540 hal.

Siringoringo R. M., Palupi R. D. \& Hadi T. A. 2012. Biodiversitas Karang Batu (Scleractinia) di Perairan Kendari. Jurnal IImu Kelautan UNDIP. 8 hal. 